\title{
ASSESSMENT OF COASTAL FLOODING AT SOUTHERN MEDITERRANEAN WITH GLOBAL OUTLOOK FOR LOWLAND COASTAL ZONES
}

\begin{abstract}
Nabil M. Ismail ${ }^{1}$, M.ASCE, Moheb Iskander ${ }^{2}$, Walid El-Sayed ${ }^{2}$
This paper presents an assessment of the performance of a shoreline revetment; M. Ali Seawall, placed to protect the land behind against flooding and overtopping at coastal site, within Abu Qir Bay, East of Alexandria along the Nile Delta coast. Coastal zone management of the bay coastline is of utmost significance to the protection of the low agricultural land and the industrial complex located in the rear side of the seawall under the current and progressive effects of climate change. The latest storm in December 2010, which hit the Nile Delta and which was the severest in the last decades showed that generated surges, up to $1.0 \mathrm{~m}$ as well as a maximum of $7.5 \mathrm{~m}$ wave height in the offshore of Alexandria presented a major natural hazard in coastal zones in terms of wave run up and overtopping. The storm, fortunately, resulted in a partial and modest flooding of the zone behind the seawall particularly in the beach segment, located in the middle of the seawall. This research project aims to the design review of the seawall which was first constructed in 1830 to protect the lowland agricultural area, $2.0 \mathrm{~m}$ below mean sea level, and was rehabilitated in 1981 as part of the Master Plan of the Nile Delta Coastal Zone Management. The seawall was further upgraded in 2009; one year before the 2010 storm. The paper will give an overview of the seawall design and its upgrades and the current conducted hydrodynamic analyses to estimate wave height distributions, wave run up and overtopping over the seawall and its beach segment. Use has been made of the in-house modified ImSedTran-2D model as well as universal design standards as EurOtop (2008). Based on the results for worst design scenarios, recommendations are given to increase the height of the seawall cap, to strengthen the beach top and back slope with a facility to drain storm water to increase coastal resilience behind the seawall. Comparison of the predicted overtopping with the observed wave overtopping volumes during the $8 \mathrm{hrs}-2010$ storm, allowed the verification of the used universal design tools. Impact of precise estimate of storm and barometric surge as well as seawall armor roughness and shapes on overtopping rates are highlighted.
\end{abstract}

Keywords: storm surges, coastal flooding, coastal resilience, seawalls

\section{BACKGROUND \& OBJECTIVES}

In recent years, the impacts of natural disasters are more and more severe on coastal lowland areas. With the threats of climate change, sea level rise and potential subsidence, the reduction of natural disasters in coastal lowland areas receives increased attention. Storm surges present a major natural hazard in coastal zones. Moreover many of the world's coastal zones are densely populated, heavily farmed with ground water overuse and increased coastal construction development. Yet many of their inhabitants are becoming increasingly vulnerable to flooding, and conversions of land to open ocean. Many barrier islands in the world such as that in the East Coast of the US and lowland and deltas such as in Italy and the Nile Delta (Fig. 1) are also experiencing significant levels of erosion and flooding. The Rosetta headland of the Nile Delta, on the western coast of the Nile delta, has been subjected to the most severe erosion of the delta coastline due to the absence of the Nile sediments since 1964 ( Fig. 2).

Sediment erosion from the headland is contributing to the coastal sediment budget in its adjacent Abu Qir bay, where M.A. seawall is located (Fig. 3). The Rosetta seawalls are currently protected by two flanking seawalls since 1990 (Fig. 4). The recent coastal flooding in Alexandria on December 12, 2010 on the Nile Delta Coastline is a striking example of the severity of more progressive global events. Egypt was hit by strong winds, exacerbated by heavy precipitation, up to $60 \mathrm{~km} / \mathrm{hr}$ with a surge of over $1.0 \mathrm{~m}$. Although reported values of storm-surge on the Nile delta coast are typically from 40 to $50 \mathrm{~cm}$, a preliminary analysis, based on the equations developed by the Dutch-Engineers on stormsurge in Zuider-Zee (Wiegel, 2005), yielded a storm-surge 0.7 to $1.5 \mathrm{~m}$ (Ismail, 2011). This range coincides with the maximum reported value of $1.2 \mathrm{~m}$ provided by Egypt-Navy.

Coastal Zone Management of Nile Delta Coastline: The coastal zone of the Nile Delta similar to most of the world's low-lying coastlines is currently affected by wave-dominated coastal processes. The Nile delta coastline has been subjected to significant coastal changes due to a combination of several factors. The main factors are the general decrease and current absence of the Nile discharge and sediment load to the Nile promontory mouth due to the construction of water control structures. The last structure was the Aswan High Dam which started operation in 1964 (Inman et al, 1984).

${ }^{1}$ Prof. of Coastal Engineering, Department of Construction Engineering, AASTMT, Alexandria, Egypt \& Director of Costamarine Technologies, Davis, California USA; email: nbismail@usa.net ${ }^{2}$, Researchers, Ph.D., Coastal Research Institute, 15 El-Pharaana Street, Alexandria 21514, Egypt; emails: Moheb Iskander: coastal_alex@yahoo.com, "Walid El Sayed" walidelsayd@yahoo.com. 


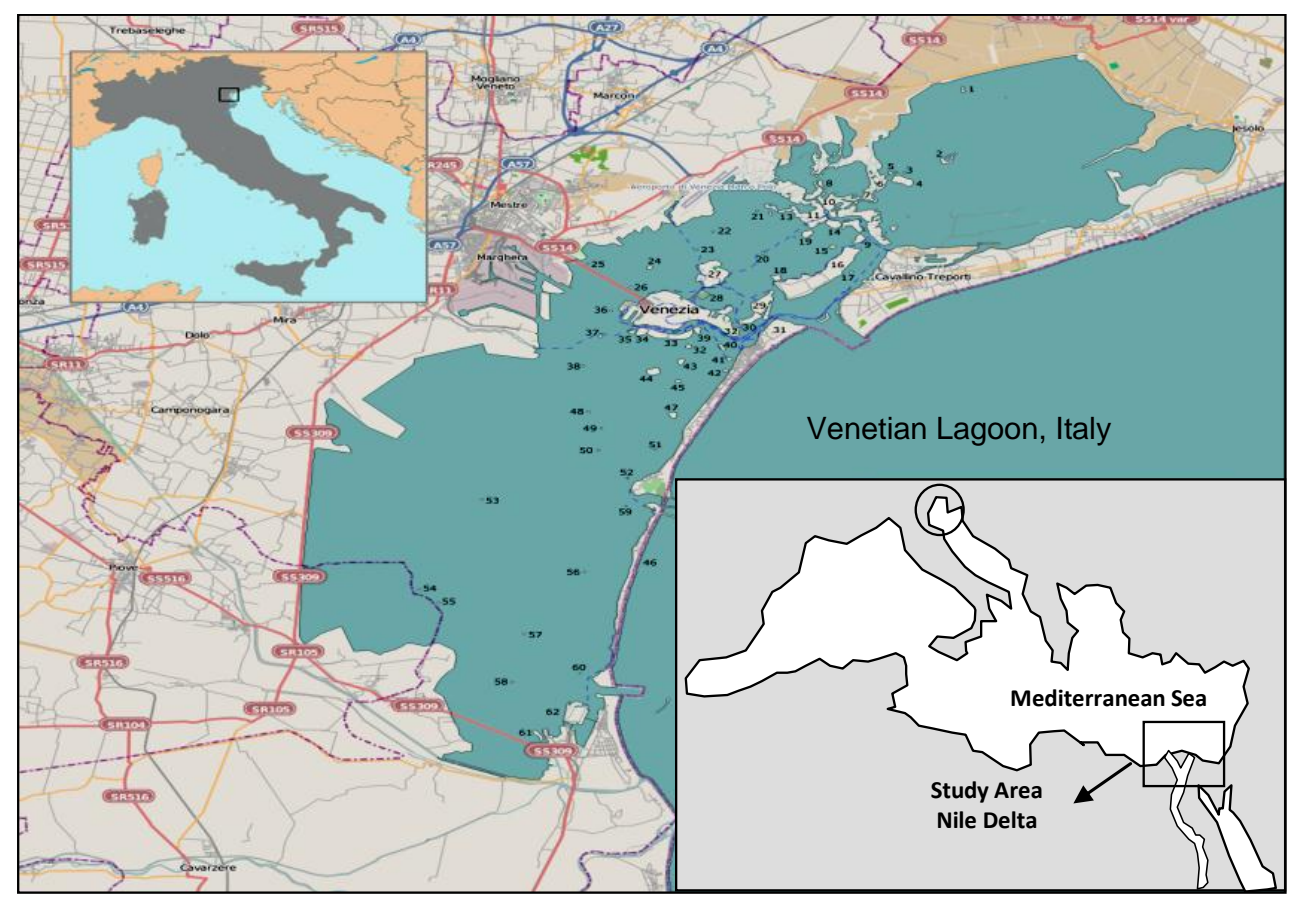

Figure 1. Typical location of coastal flooding problems due to erosion and subsidence in Italy, \& Egypt
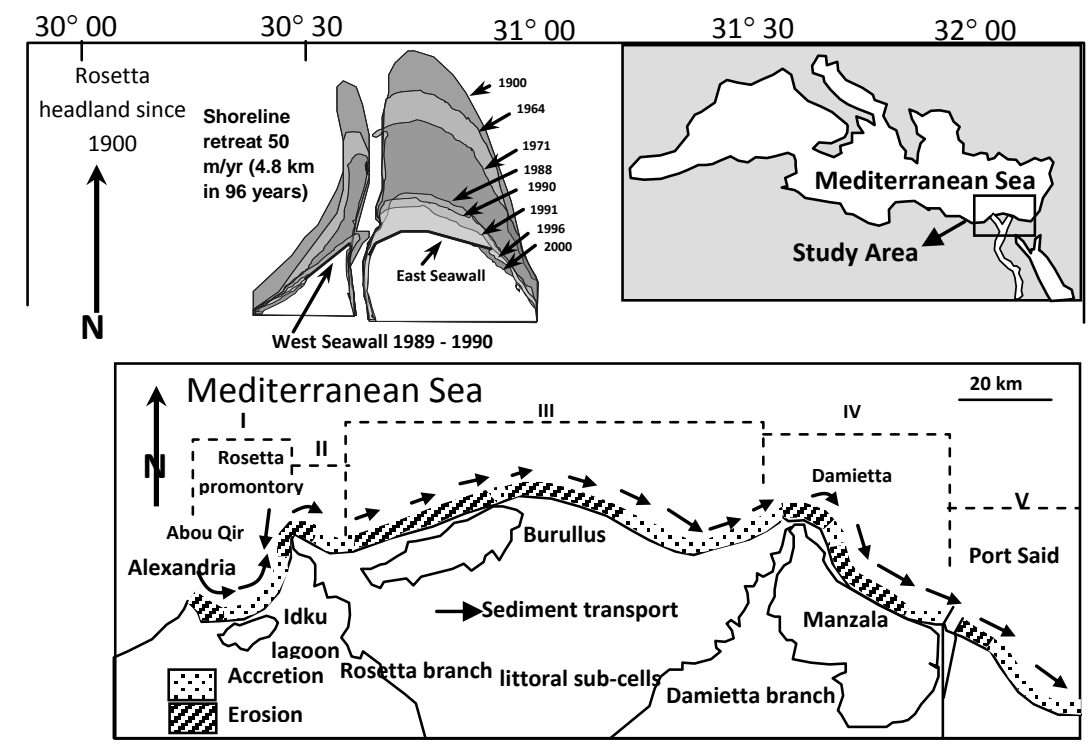

Figure 2. Erosion and accretion patterns and littoral sub-cells along the Nile Delta coastline after the construction of Aswan high dam 


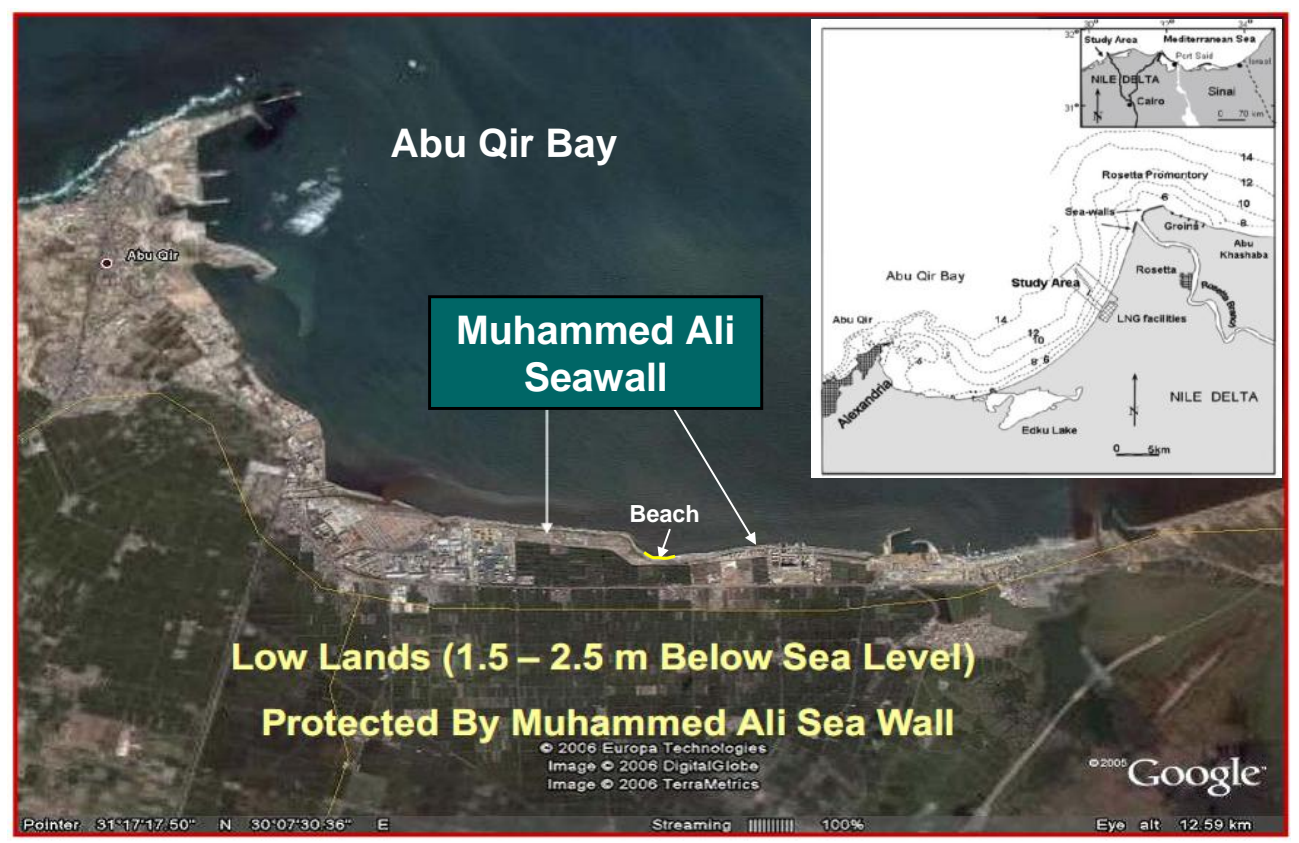

Figure 3. Muhammad Ali seawall (1830-present), Abu Qir Bay, Nile Delta coastline

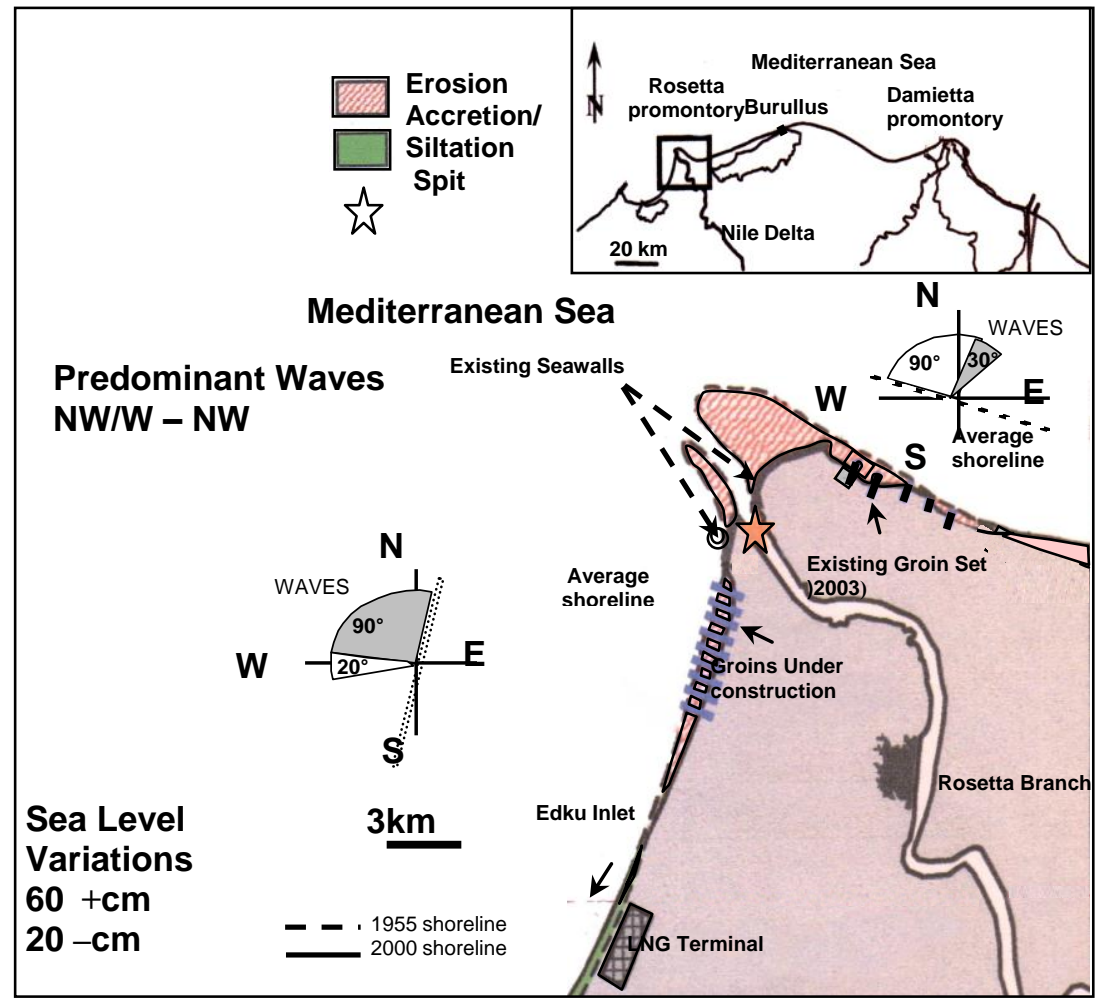

Figure 4. Morphological changes at Rosetta promontory headland 
A comprehensive program has been underway since 1970 by the government coastal protection agencies for more than four decades to collect nearshore data related to coastal erosion problems along the Nile Delta. Review of major existing coastal problems along the Nile delta coast and general description of the protective structures that have been implemented to address these problems are given by Mobarak (1972), Fanos et al (1995) Kadib et al (1986), and Khafagy et al (1992). The responsibility of planning major protection coastal projects since 1975 has been managed by the Coastal Research Institute in Alexandria with its construction counterpart, the Coastal Protection Authority in Cairo. A review of major coastal protective structures which were implemented 1980 to 2007 is briefed more recently by Frihy, Iskander, El Sayed (2006), Ismail and El-Sayed (2007). These coastal structures succeeded to mitigate and slow considerably coastal erosion in major locations along the Nile Delta coastline.

Global Climatic Changes and Coastal Vulnerability: At a global scale, an example of the effects of accelerated climate changes was demonstrated in autumn 2010 when the storm Becky reached the Santander Bay, Spain. As reported by THESEUS, the FP-7 EU project (2009-2013), the peak of nearshore significant wave height was about $8 \mathrm{~m}$, the storm surge reached $0.6 \mathrm{~m}$, with tidal level of $90 \%$ of the tidal range. This storm reflected at least a 20 years return period event. The recent coastal flooding in Alexandria on December 12, 2010, on the Nile Delta coastline is a striking example of the severity of more progressive events. Egypt was hit by strong winds, exacerbated by heavy precipitation, up to $60 \mathrm{~km} / \mathrm{hr}$ with a10 hrs duration. These weather conditions resulted in waves of more than $6.5 \mathrm{~m}$ height with a surge of over $1.0 \mathrm{~m}$ which forced the closure of Alexandria main harbor. The typical reported significant wave height is about 1.0 to $1.5 \mathrm{~m}$ for NW/WNW waves under normal weather. Maximum waves height during storm conditions has an average of $4.5 \mathrm{~m}$. Typical values of storm surge on the Delta coast are from 40 to $50 \mathrm{~cm}$ while the measured value of $1.2 \mathrm{~m}$ for storm surge was provided by Egyptian Navy during the latest storm. The tidal range typically varies from 40 to $60 \mathrm{~cm}$ at Alexandria. The latest storm left a pronounced mark on Alexandria coastal highway, its adjacent Abu Qir Bay as well as on lowland shorelines between the two river Nile promontories, Rosetta and Damietta. The damage mechanisms resulted from direct wave \& wind forces, wave run up \& wave overtopping, flooding and sand over wash.

Project Site and Mohamed Ali Seawall: Rosetta headland with its adjacent Abu Qir Bay forms a unique lowland coastal littoral cell, in which sedimentation is controlled by a combination of environmental factors such as waves, current, tides and minute river discharges after the operation of the High Aswan Dam in 1965. Abu Qir Bay (Fig. 3) is a shallow semi-circular basin lying $35 \mathrm{Km}$ east of Alexandria city. The bay has a shoreline of about $50 \mathrm{Km}$ long and the maximum water depth of about $16 \mathrm{~m}$. The inland portion was considered a fertile agricultural lowland zone when compared with the other portions of the Nile Delta Mediterranean coastal fringe. This warranted and motivated the Ottoman ruler Mohamed Ali to construct a seawall in 1830 to protect the vast agriculture land against sea flooding. The land is lower than the mean sea level with an average of $2 \mathrm{~m}$ (Fig. 3). The seawall was repaired and upgraded in 1981(Figs.5, 6), and a beach segment (Fig. 3) was created at an appropriate location for recreation (Fig. 7). The seawall was rehabilitated twice during the last several decades and more recently upgraded in the year 2011 after the 2010 storm. As in many coastal regions near major urban areas, the bay is used for variety of purposes: commercial fishing, shipping, recreational boating, swimming as well as its inland portion embraces several industrial complex, a thermal power plant and an export Liquefied Natural Gas (LNG) terminal which was constructed in 2004.

Objectives: The main objective of this paper is to examine the current design integrity of Mohamed Ali seawall (revetment) in the partially protected Abu Qir Bay under scenarios of the extreme events under the conditions of today and tomorrow necessary for risk analyses. These conditions include; wave heights, storm surge as well as effects of mean sea level rise due to global warming.

\section{NILE DELTA PROJECT AND ABU QIR BAY}

The absence of river currents modified the nearshore circulation induced by wave-current interaction which maintained the delta shape for many centuries. A comprehensive program has been underway by the government coastal protection agencies since 1975. 


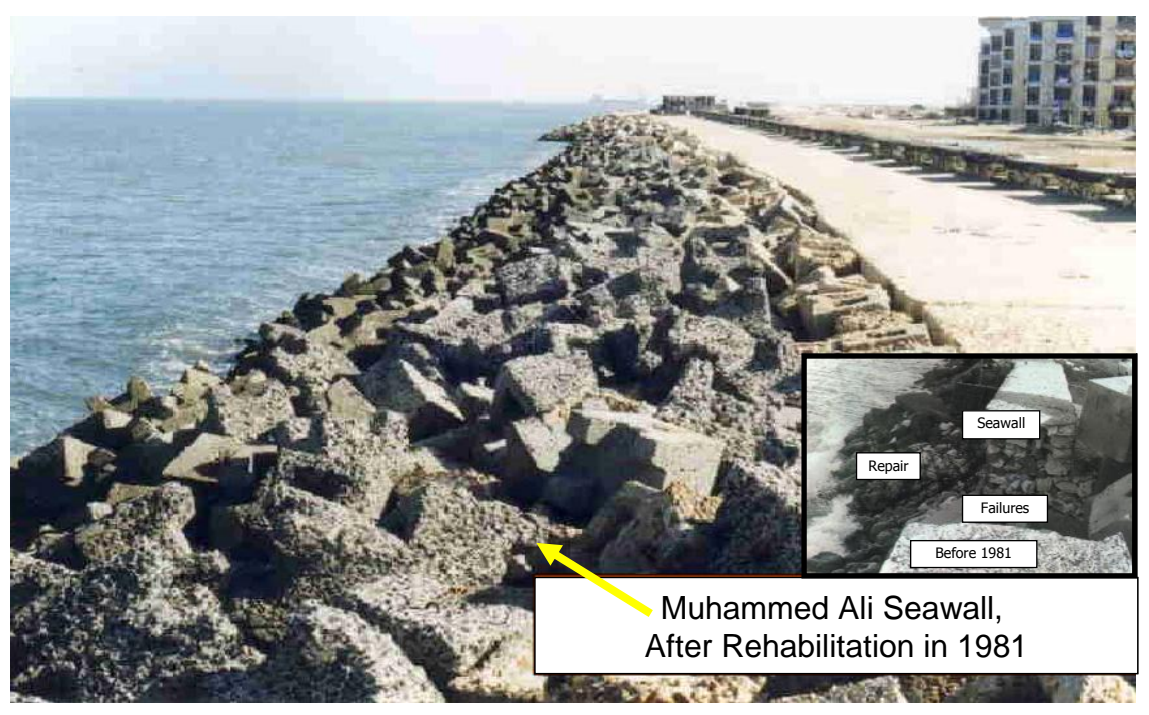

Figure 5. View of Muhammed Ali seawall and residential area for power plant

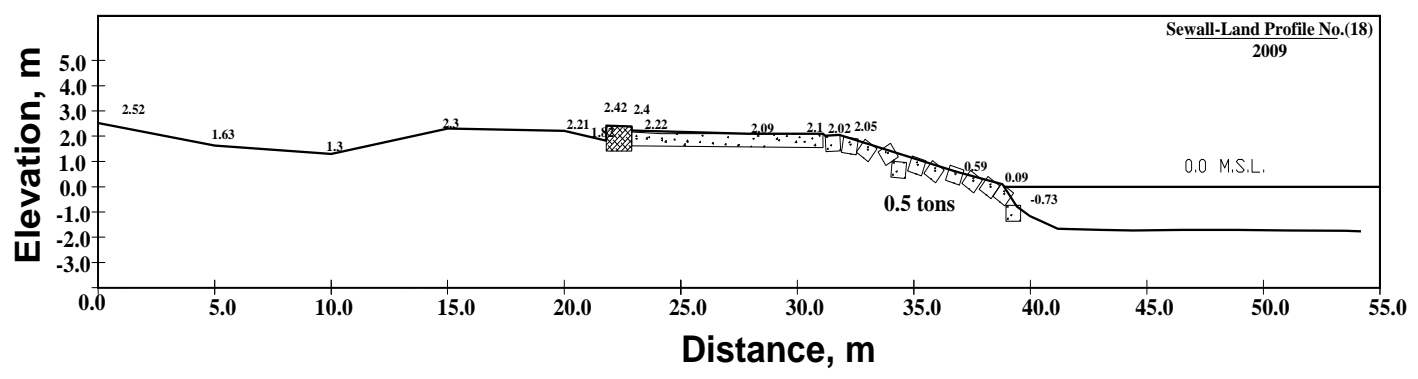

Figure 6. Profile of seawall cross section 1981-2009

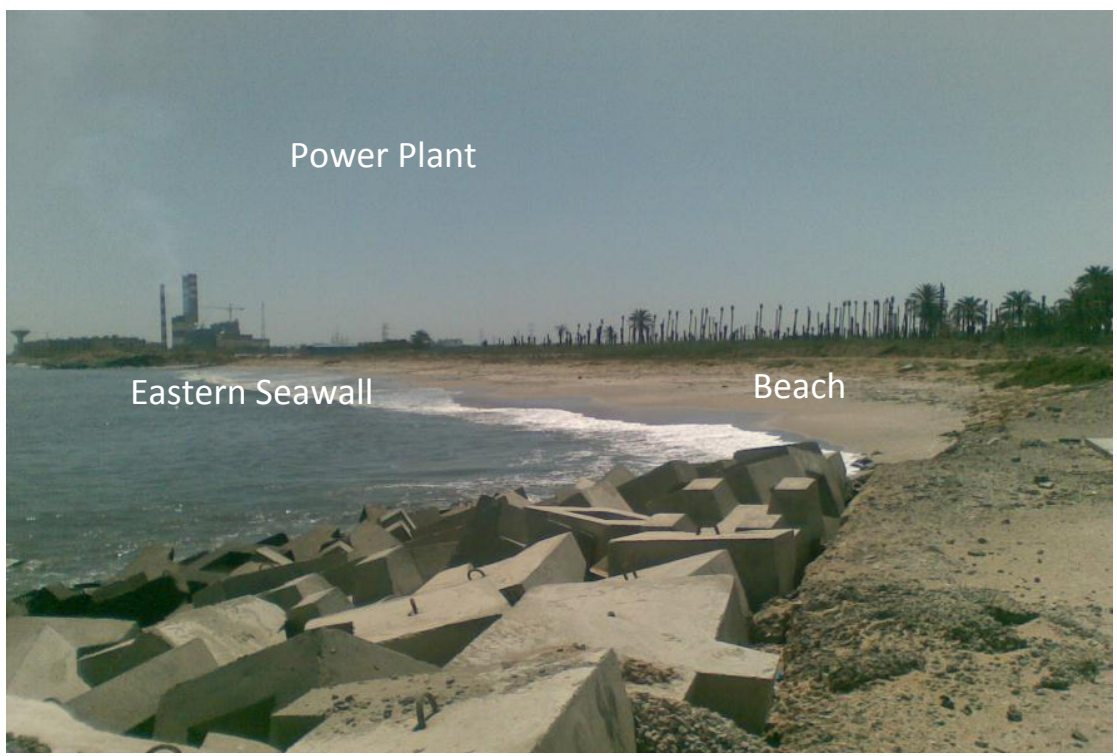

Figure 7. View from the western portion of M. Ali seawall 
Rosetta-Headland Seawalls: A notable case study of the drastic modifications which occur to the cross shore profiles and adjacent shorelines at seawalls is the case of the two seawalls constructed at the Rosetta Promontory between 1989 and 1990 (Fig. 4) to decelerate the Rosetta headland rapid retreat after the operation of the Aswan High Dam in 1964.

Figures 2 and 4 show the historical evolution of the Rosetta headland and shoreline modifications after the completion of the two seawalls which were constructed inland. To reduce the impact of the shoreline retreat at Rosetta promontory, two dolos seawalls (4-7 tons) were constructed between 1989 and 1990 on both sides of the Rosetta Nile branch mouth (Fig. 4). The western and eastern seawalls were constructed inland and extend alongshore to a length of $1.5 \mathrm{~km}$ and $3.35 \mathrm{~km}$, respectively. The rate of shoreline changes after the construction of the seawalls revealed that the protection had succeeded in stopping retreat and flooding of the headland. However, coastal changes have shifted the shoreline modifications (erosion \& accretion) to downdrift areas at the end of the seawalls. Subsequently, groin systems were built at the eastern side and are being constructed on the western side, to combat the erosion that resulted at the downdrift areas (Fig. 4).

Abu Qir Bay, which has a shoreline of about $50 \mathrm{Km}$ long and a water depth ranging from $16 \mathrm{~m}$ near the offshore to $2 \mathrm{~m}$ in front of the sea wall, has a surface area of about $360 \mathrm{Km}^{2}$. (Debes, 2002). As in many coastal regions near major urban areas, the bay is used for variety of purposes; commercial fishing, shipping, recreational boating, swimming and as a repository for industrial and cooling water effluents. During the last decades, the bay has been facing the problem of pollution discharges from different sources; El-Tabia Drainage Pumping Station (TPS), the El-Tarh Thermal Power Station and the Rosetta branch of the Nile which are currently being under EPA control.

M. Ali revetment was constructed (1830) to protect the agriculture lowland area in Abu Qir bay for over 200 years ago. The seawall was maintained several times during the period from 1920 to 1930. In 1981, under the terms of the Nile Delta Master Plan conducted jointly with Tetra Tech Inc. (Pasadena, CA, Kadib) the protection work modified the seawall to revetment with front slope 1:2 and 0.50 ton concrete cubes as armor layer. The top level of the revetment is ranged from 2.0 to $3.0 \mathrm{~m}$ depending on the degree of exposure to the sea. In 2007, the new plan to enforce the revetment as well as the structure toe started to be implemented by increasing the weight of the armor layer from 0.5 ton to 2.0 ton. The main target for these modifications was to increase the lifetime of the structure and to increase the stability of the structure related to the effect of the climate changes. From 2008 to 2011, only five kilometers from the total length $(6.0 \mathrm{~km})$ of the revetment was upgraded.

\section{VULNERABILITY ASSESSMENT OF ABU QIR M. ALI SEAWALL}

Wave overtopping occurs when individual wave crests exceed the 'freeboard' (height above still water level) of the coastal defenses causing further flooding beyond that due to the surge. See Pullen et al. (2007) for the coastal engineering approach to overtopping. The impact of waves at the coast also includes breaking and run up on beaches and foreshores which can cause coastal erosion depending on the configuration of the coast and the supply of mobile sediment. There is an increased risk of devastation due to socio-economic factors as the flood.

A review was made of the data of incident wave heights and storm surge for the Nile Delta coastline, at the locations of damaged/undamaged sites, cross-shore profiles at these sites as well as the description of existing protection systems.

The Wave climate at Abu Qir Bay is reflected by a maximum $3.5 \mathrm{~m}$ wave height for a return period of one year with corresponding wave period range between 5.5 and $9.5 \mathrm{sec}$ ( $7.5 \mathrm{sec}$ in average). The wave direction is from $\mathrm{N}$ to $\mathrm{NW}$. This maximum wave creates breaking wave conditions near the seawall with a wave height around $1.6 \mathrm{~m}$.

Wind waves and elevated water levels together can cause flooding in low-lying coastal areas, where the water level may be a combination of mean sea level, tides, setup, and storm surges. In areas with a wide continental shelf, a travelling external surge may be combined with the locally generated surge and waves and there can be significant interaction between the propagation of the tide and surge. Wave height at the bay coast is controlled largely by water depth and therefore the effect of tides and impact of surges on waves must also be considered. These processes, although they are well understood, they need to be accurately predicted by models. These models must include the effects of other processes accounting for the effects of surface wind-stress, bottom friction, and refraction of waves. 
Detailed calculations of storm surge, over complex topographical conditions, are complicated and require advanced numerical models. However, for the geometry of the Abu Qir bay, it is justified to obtain the modified values of the water depth, due to storm surge through a simpler approach. The storm surge could be obtained from the numerical solution of the surge governing equation with initial values equal to zero in deep water and moving towards the bay shoreline with the greatest values in shallow water at the seawall. The design values of storm surge under the maximum yearly storm conditions were numerically calculated to obtain the expected increase of water depth, due to storm, at the seawall. A design value of $0.5 \mathrm{~m}$ was considered for the current research and which corresponds to the field data available from the Egyptian Navy as well as that referenced by Debes (2002). In the following section, hydrodynamic analyses accounting for the effects of water depth changes, tide level, storm surge, and sea level rise will be conducted to obtain the wave height distributions at the seawall and correspondingly, wave run up and overtopping rates will be estimated.

\section{HYDRODYNAMIC ANALYSES OF WAVE RUN UP AT ABU QIR SEAWALL}

In the current study, the in-house modified ImSedTran-2D model which is based on the Perlin and Dean numerical model (1983) is applied to determine wave distributions along the study area under the effects of changes in bed morphology and wave characteristics for the next 50 years, which corresponds to the coastal structure's lifetime. The model, which has been validated over a number of previous projects and against the output of other international software packages, uses input data of wave characteristic, bed morphology, coastal structures and bed sediment characteristics. Future changes of water depth in the bay for the effect of sea level rise (SLR), were estimated using the data of the Coastal Research Institute (Shinnawy et al., 2010) as shown in Table (1). The total value accounting for SLR and storm surge was taken $1.0 \mathrm{~m}$.

\begin{tabular}{|c|c|c|c|c|c|}
\hline \multirow{2}{*}{ City } & \multirow{2}{*}{$\begin{array}{c}\text { IPCC } \\
\text { Scenario }\end{array}$} & \multicolumn{4}{|c|}{ Year } \\
\hline & & 2025 & 2050 & 2075 & 2100 \\
\hline Alexandria & \multirow{3}{*}{ A1F1 } & 13.0 & 34.0 & 55.0 & 72.0 \\
\hline Burullus & & 14.75 & 37.5 & 60.3 & 79.0 \\
\hline Port Said & & 27.9 & 68.8 & 109.6 & 144.0 \\
\hline
\end{tabular}

The wave diffraction calculation based on the Kraus (1984) solution is used to simulate the wave condition in the vicinity of the coastal structures. The wave height at the location in question is simply the product of the specified partially refracted incident wave height and diffraction coefficient. The angle of the wave crest is computed assuming a circular wave front along any radial; this angle is then refracted using Snell's law. Throughout the refraction and diffraction schemes, the local wave heights were limited by the value 0.78 of water depth. Calculations of the wave distributions are based on shoaling processing, refraction, diffraction, and depth limited breaking. The model is designed to take the actual wave data measurements as well as the water depth at any point offshore of the wave breaking point.

Two design scenarios were considered to estimate wave height distributions within Abu Qir Bay and along M. Ali seawall. The following modules are built with input of the changes of water depth due to tide and storm surge (Debes, 2002):

1. Recent morphology with the maximum yearly wave condition $\left(\mathrm{H}_{\max }=3.50 \mathrm{~m}, \mathrm{~T}=7.5\right.$ sec., $\mathrm{N}$ direction, Depth= $14.0 \mathrm{~m})$.

2. Future morphology (recent bathymetry + the sea level rise within the next 50 years) with the maximum yearly wave condition.

The model results of wave height distributions are shown in figures $(8 \& 9)$ and which indicate the following:

- The wave energy within the surf zone decreases westward due to the effect of the bed morphology and Abu Qir Harbor breakwater (Fig. 3).

- The wave energy is concentrated on the artificial headland east of the western seawall.

- The sea level rise has a noticeable effect for the case of maximum wave condition. The wave height in front of the coastal structure at the toe will increase by about $25 \%$ after 50 years. 


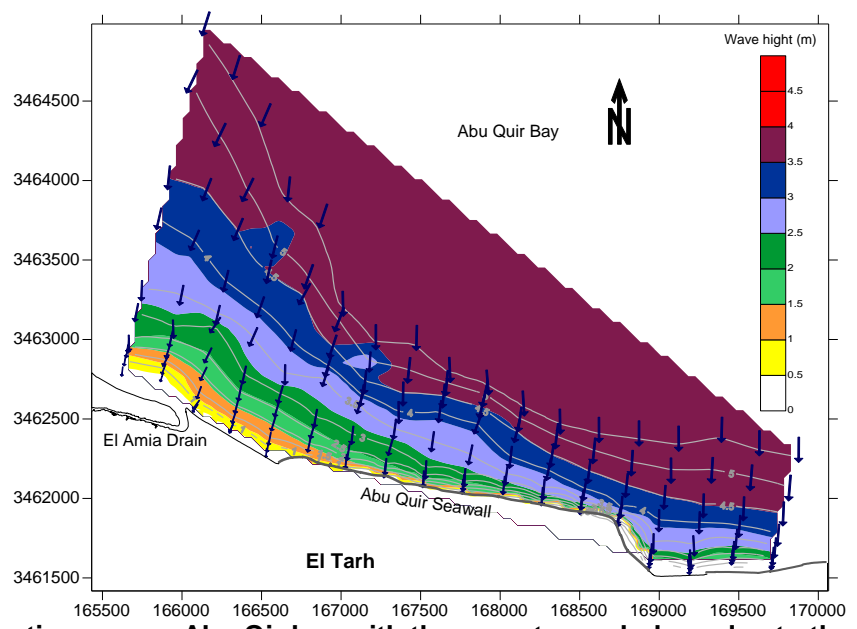

Figure 8: Wave distribution across Abu Qir bay with the recent morphology due to the maximum yearly wave condition (wave height is denoted by the color scale in meters and wave direction by arrows).

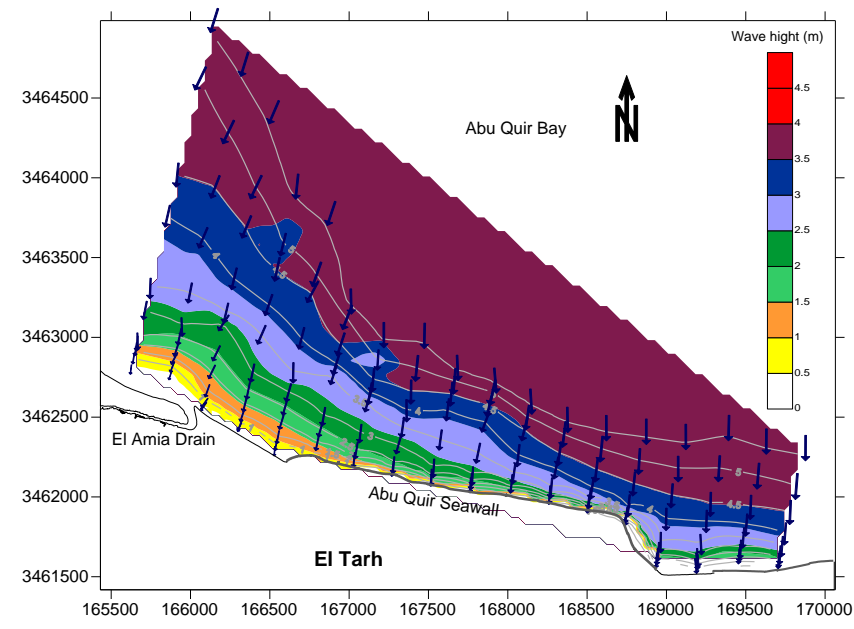

Figure 9: Wave distribution across Abu Qir bay with the future morphology due to the maximum yearly wave condition (wave height is denoted by the color scale in meters and wave direction by arrows).

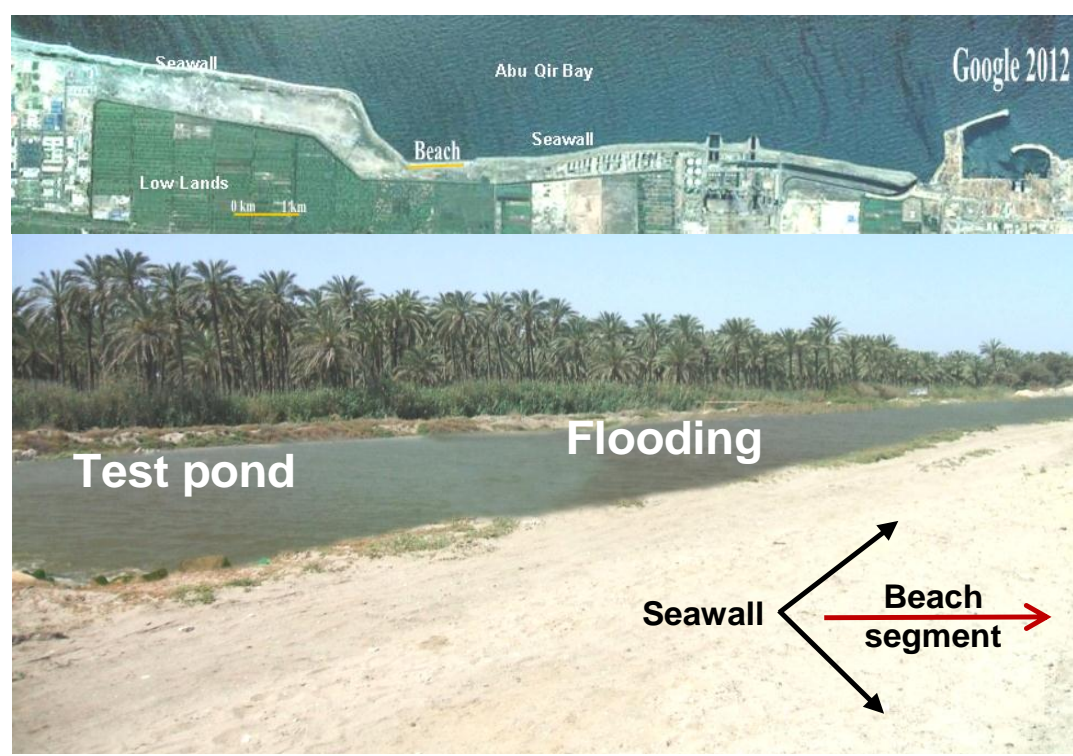

Figure 10: View of wave flooding over the beach segment after the December 2010 storm 
The increase in wave height will not threaten the stability of the seawall but the wave run up and overtopping will be increased extensively. Wave overtopping has been of principal concern for the lowland behind the seawall since the $18^{\text {th }}$ century. More recently the construction of the power plant and concern for its safety required taking sufficient measures to provide protection against shore erosion and flooding.

The general design formula that can be applied for wave run up on dikes is given by J. W. van der Meer (1998):

$$
\mathrm{R}_{\mathrm{u} 2 \%} / \mathrm{H}_{\mathrm{s}}=1.6 \gamma_{\mathrm{b}} \gamma_{\mathrm{f}} \gamma_{\beta} \xi_{\mathrm{op}} \text { with a maximum of } 3.2 \gamma_{\mathrm{f}} \gamma_{\beta}
$$

with: $\gamma_{\mathrm{b}}=$ reduction factor for berms,

$\gamma_{\mathrm{f}}=$ reduction factor for slope roughness and

$\gamma_{\beta}=$ reduction factor for oblique wave attack.

where:

$$
\xi_{\text {op }}=\text { the breaker parameter, } \xi_{\text {op }}=\tan \alpha / \sqrt{S}_{o p}
$$

$\alpha=$ the average slope angle and $\mathrm{S}_{\mathrm{op}}=$ the wave steepness.

$\mathrm{H}_{\mathrm{s}} \quad$ = significant wave height.

Equation (1) is valid for the range $0.5<\gamma_{\mathrm{b}} \xi_{\mathrm{op}}<4$ or 5 . The relative wave run up $\mathrm{Ru}_{2 \%} / \mathrm{H}_{\mathrm{s}}$ depends on the breaker parameter $\xi_{\text {op }}$ and on the three reduction factors, namely: for berms, for roughness of the slope, and effects for oblique wave attack. The influence of the roughness on the slope is given by the reduction factor $\gamma_{\mathrm{f}}$. Reduction factors for various types of revetments have been published by Bruce et al (2006). Correspondingly, there is influence of armor roughness and permeability which should be taken into consideration in calculations and models to estimate wave run up and overtopping rates.

Estimates of run up and rates of wave overtopping were obtained from design formulas and computer programs endorsed in the following references:

- "Wave Run Up and Overtopping on Coastal Structures", De Waal, J. P., and van der Meer, J. W. 1992.

- "Wave Run Up and Wave Overtopping at Dikes," van der Meer, J. W., and Janssen, J. 1994

- "Manual of Wave Overtopping of Sea Defenses", EurOtop, (2008), www.overtopping-manual.com

Validation of the estimated wave overtopping rates $(20 \mathrm{~L} / \mathrm{s} / \mathrm{m})$ during the $8 \mathrm{hrs}$ storm duration was obtained by measuring the volume of seawater accumulated in the pond behind the beach immediately after the storm (Fig. 10). The results of numerical calculations for the two design scenarios addressed above are listed in Table 2 and displayed in Figure 11. The obtained results suggest modifications of the design made in 2011 by raising the height of the seawall cap as well as the beach top and to strengthen the beach dike back slope to meet future challenges under extreme storm surge events (Fig. 12). Such design improvement is a required step to meet the challenge to vulnerability of lowland coastal areas. Moreover, allowance should be made to have well maintained drainage systems and ditches in the rear of the seawall and the beach segment to collect excess overtopped seawater during extreme storms and to divert it to the local agricultural drainage channel located upstream the power plant (Fig. 13). 


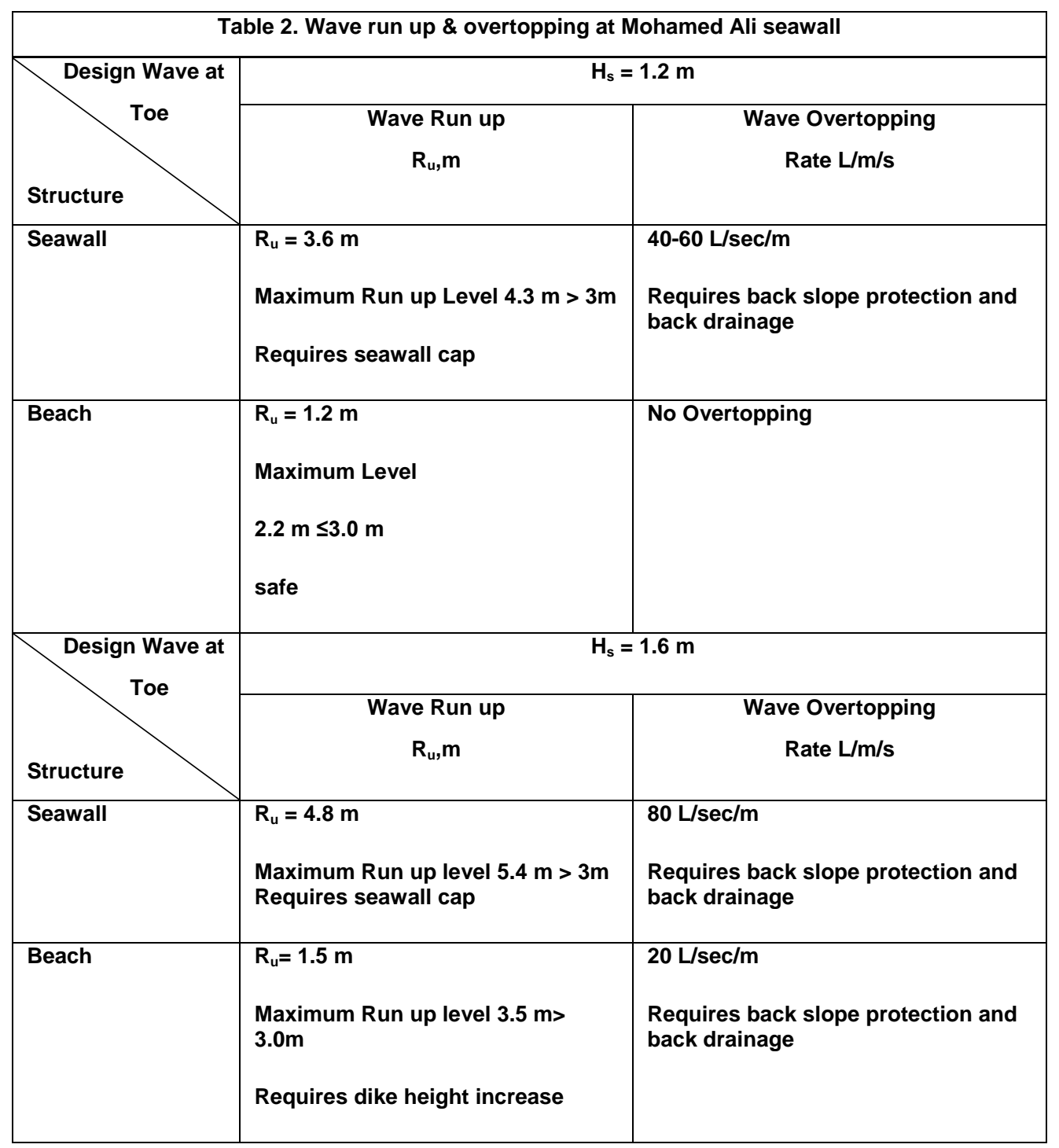




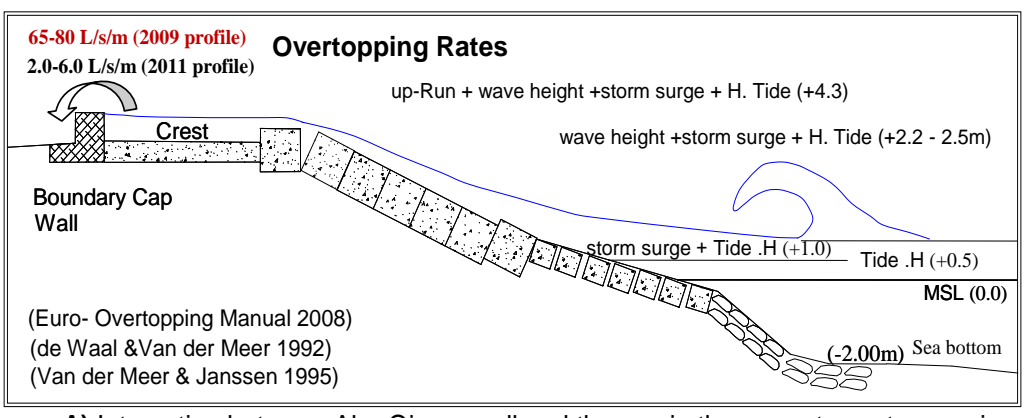

A) Interaction between Abu Qir seawall and the sea in the current worst scenario.

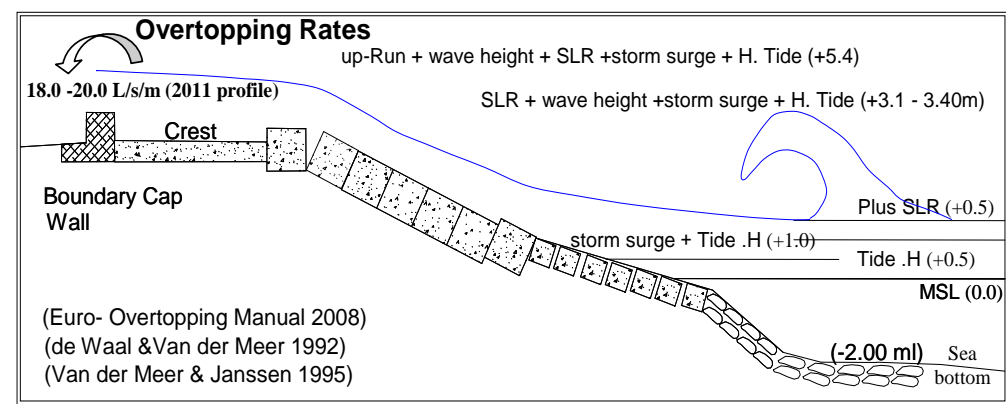

B) Interaction between Abu Qir seawall and the sea in the future worst scenario due to sea level rise after 50 years.

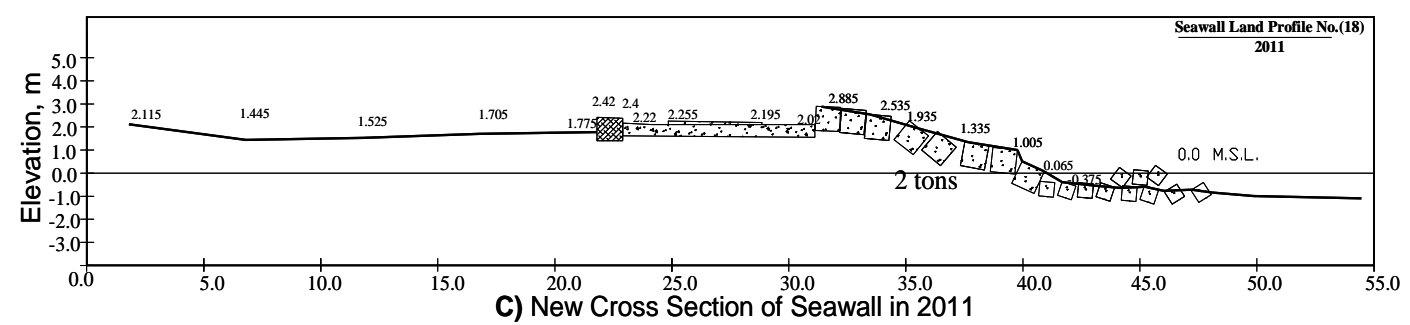

Figure 11: Results of wave run up and overtopping (A, B) and the new seawall cross section (c)
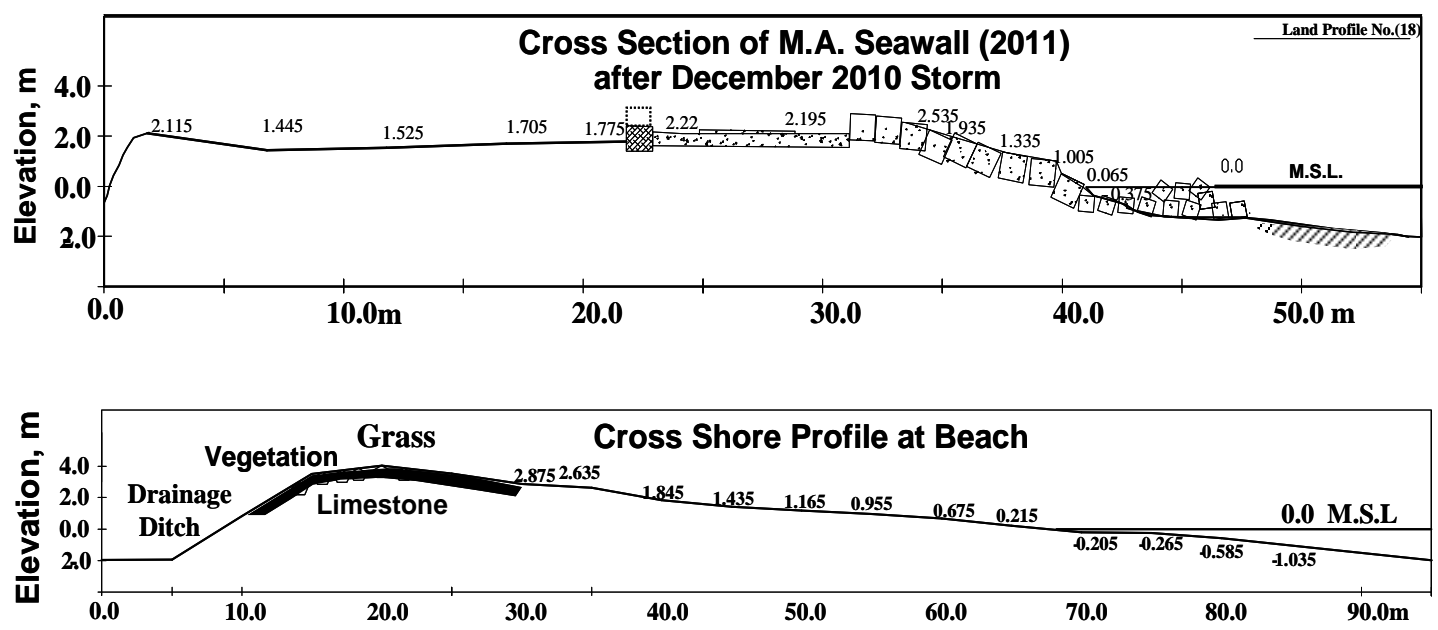

Figure 12: Recommended modifications at the lee of the seawall and beach segment for flood drainage 


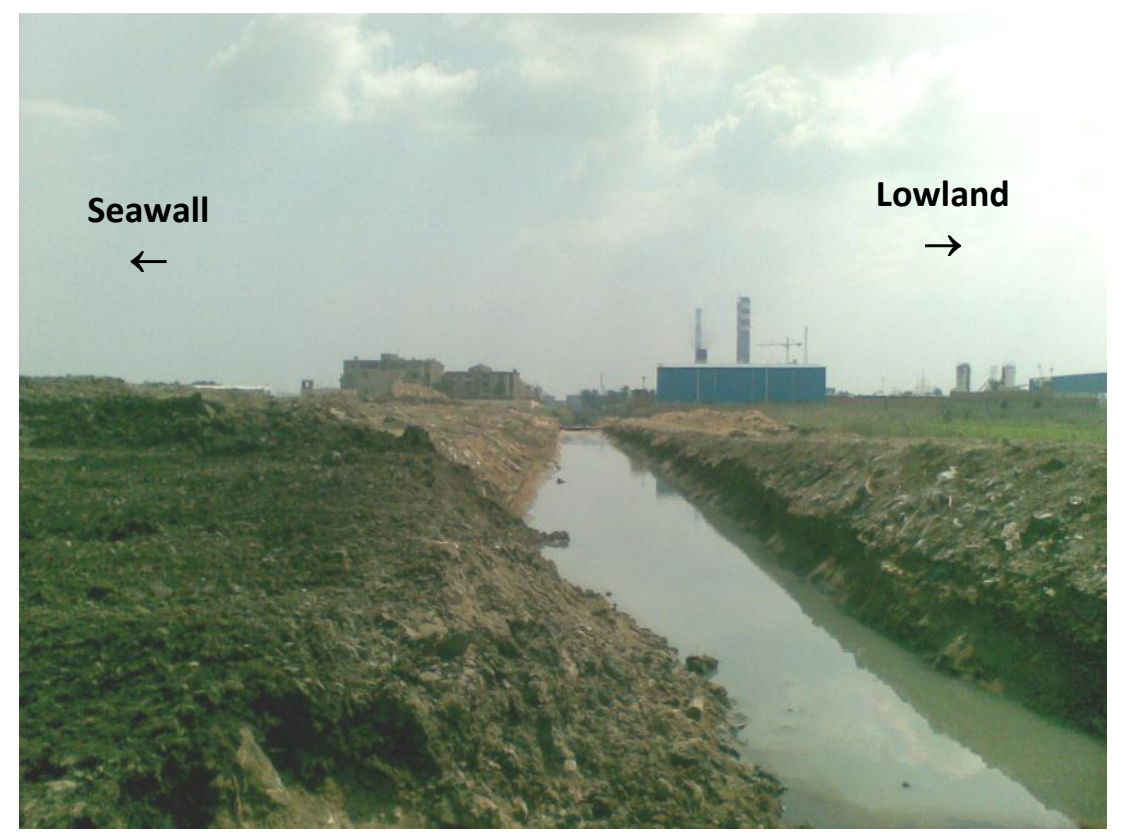

Figure 13. A view of dredging operation of the drainage channel between $M$. Ali seawall and the power plant

\section{CONCLUSIONS}

The main drive of the current research project is to ensure the sustainability of lowland areas behind M. Ali seawall, located along the Abu Qir bay to a variety of natural hazards.

The results of the hydrodynamic analyses show that seawall upgrade conducted in 2011 was a necessity and in which the top level of the seawall was raised to 2.9-3.0 m. Further, the expected sea level rise and estimated storm surge have a dramatic effect for the case of maximum storm wave condition at Mohamed Ali seawall. The wave height in front of the seawall area will increase by about $30 \%$ in the next $25-50$ years. The expected increase in wave height at the seawall will not threaten the stability of the current design of the seawall but the wave overtopping will be increased extensively. Therefore the seawall cap needs to be raised in height with a facility to drain the flood water. Accurate prediction of storm surge using non-linear interaction models is recommended.

The results show that future climatic changes indicate that it is necessary to improve the stability of the back slope of the beach segment of M. Ali seawall to create wave overtopping resistance under severe storm conditions. Strengthening the top surface of the beach segment by grass vegetation and armoring the beach back slope is a necessity. Creation of ditches in the lee side of the beach to divert overtopping flood water to the main drainage channel in the lowland agricultural zones is a must.

It is recommended that monitoring of coastal subsidence in lowland coastal zones should be in focus to ensure that the top level of the seawall and the cap are maintained.

The analyses conducted in this paper should motivate coastal designers to take into consideration the influence of seawall armor types, its roughness and permeability in estimating overtopping rates as highlighted in the database of the CLASH-EU project.

This recent experience of the design review of M. Ali seawall is in line with the principles of sustainable ICZM coupled with the use of coastal models as demonstrated before in developing the Nile Delta Master Plan completed in 1981 by the Egyptian government coastal authorities and Tetra Tech, CA, USA.

\section{ACKNOWLEDGEMENTS}

The authors wish to express their deep appreciation to their colleagues of the Coastal Research Institute (CoRI), Alexandria, Egypt and its director Prof. Ibrahim El-Shinnawi and his deputy Dr. Bakr Abou-Zed for their valuable support. 


\section{REFERENCES}

Bruce, T., van der Meer, J.W, Franco, L., and Pearson J. 2006. A comparison of overtopping performance of different rubble mound breakwater armour. ASCE, Proceedings ICCE, San Diego.

De Waal, J.P., van der Meer, J.W. 1992. Wave run-up and overtopping on coastal structures. Proceedings $23^{\text {rd }}$ International Conference on Coastal Eng. ASCE, Venice, Italy, vol. 2, pp 17591771.

Debes, A.A.M. 2002. The study of sea level changes and currents at Rosetta and Damietta outlets and Abu Qir Bay. M.Sc. Thesis, Physical Oceanography Department, Faculty of Science, Alexandria University.

El-Sayed, M.k, and Ismail, N. 2011. Enhancement of cross-shore profile evolution models for sustainable coastal design, Proceedings of Conference on Coastal Engineering Practice, ASCE, COPRI, San Diego, California. August 21-24, pp 548-560.

El Shinnawy, I.A., Abo Zed A.I., Ali, M.A., Deabes, E.A., Abdel-Gawad, S. 2010. Vulnerability to climate changes and adaptation assessment for coastal zones of Egypt., Proceedings of the First International Journal on Coastal Zone Management of River Deltas and Low Land Coastlines, Alexandria, Egypt, ISSN 1110-4929, pp 145-160.

Fanos, A., Khafagy, A., and Dean, R. 1995. Protective works on the Nile-Delta coast, J. Coastal Research, vol.11, No. 2.

Frihy, O.E., Iskander M.M., El Sayed W.R., Abo Zed A.L., Selim M.A., Hassan M.S., Badr A.M. 2006. Environmental impacts monitoring of the emerged breakwaters at Asafra-Mandara beach, Alexandria, Egypt, The first International Environmental Forum, A New Strategy for Developing Communities and Environment, Tanta University, Tanta.

Frihy O.E., Iskander M.M., Bader A.M. 2004. Effect of shoreline and bedrock irregularity on the morphodynamics of Alexandria coast littoral cell, Egypt, Journal of Geo-marine Letters, vol. 24, No.4. pp 195-211.

Ha, W., Kim, K., and Lim, W. and Pyum, C. 2011. An experimental study on coastal erosion protection by submerged breakwater made of Tetrapods, Proceedings of Conference on Coastal Engineering Practice, ASCE, COPRI, San Diego, California.

Inman, D.L., and Jenkins, S.A. 1984. The Nile Delta littoral cell and man's impact on the coastal zone of the southeastern Mediterranean. Proceedings $19^{\text {th }}$ International Conference on Coastal Engineering, ASCE, Houston, Texas, vol. 2. pp 1600-1617.

Iskander, M.M. 2005. Simulating some coastal problems in Egypt using numerical modeling, Ph.D. thesis, Faculty of Engineering, Alexandria University, 170p.

Iskander, M., Frihy, M., Omran E., El Ansary, A.E., Abd El Mooty, M., Nagy, H.M. 2007. Beach impacts of shore-parallel breakwaters backing offshore submerged ridges, Western Mediterranean Coast of Egypt, Journal of Environmental Management, vol. 85, Issue 4, pp 1109-1119.

Ismail, N. M. 2011. Assessment of recent coastal flooding in Alexandria and future outlook for the Nile Delta, Geophysical Research Abstracts, vol. 13, EGU2011-13656, EGU General Assembly, Vienna, Austria, April 3-8.

Ismail, N., and El-Sayed, W. 2007. Coastal processes at Rosetta-Headland and seawall-beach interaction, Proceedings of International Conference on Coastal Structures, ASCE, Venice, Italy, July 2-4, vol. 1, pp 490-501.

Ismail, N.M. and Wiegel, R.L. 2003. Secondary flows and sediment problems near coastal marine outfalls. Proceedings $3^{\text {rd }}$ International Conference on. Coastal Structures, ASCE, Portland, Oregon, USA, pp 764-776.

Ismail, N.M. 1982. Effect of wave-current interaction on littoral drifts, Shore and Beach, J. American Shore \& Beach Preserv. Assoc., vol. 50, No. 1, pp 35-38.

Kadib, A.L., Shak, A.T., Mazen, A.A. and Nadar, M.K. 1986. Shore protection plan for the Nile Delta coastline. Proceedings $20^{\text {th }}$ International Conference on Coastal Engineering, Taipei, Taiwan, vol. 3, pp 2530-2544.

Kraus, N.C. 1984. Estimate of breaking wave height behind structures. Journal of Waterway, Port, Coastal, and Ocean Engineering, ASCE, vol. 110, pp 276-282.

Perlin, M., Dean, R.G. 1983. A numerical model to simulate sediment transport in the vicinity of coastal structures. Miscellaneous Report No. 83-10, US Army, Corps of Engineers, CERC, Fort Belvoir, 199p. 
Pullen, T Allsop, N.W.H., Bruce, T., Kortenhaus A, Schüttrumpf H., van der Meer, J.W. 2009. EurOtop - overtopping and methods for assessing discharge, Flood Risk Management: Research and Practice - Samuels et al. (eds), Taylor \& Francis Group, London.

Shankar N.J., Jayaratne, M.P.R., 2003. Wave run-up and overtopping on smooth and rough slopes of coastal structures, Ocean Engineering, Elsevier, vol. 30, pp 221-238.

U.S. Army Coastal Engineering Research Center, Shore Protection Manual. 1984-2002, U.S. Government Printing, Office, Washington, D.C., vol. 2. http://chl.erdc.usace.army.mil/.

Van der Meer, J.W. 1998. Wave run-up and overtopping. Chapter 8 in: "Seawalls, dikes and revetments". Ed. by K.W. Pilarczyk, Balkema, Rotterdam.

Van der Meer, J.W., and Janssen, J.P.F.M. 1994. Wave run-up and wave overtopping at dikes, ASCE. In: Wave forces on inclined and vertical wall structures, Ed. by N. Kobayashi and Z. Demirbilek.

Wiegel, R.L. 2005. Oceanographical Engineering, Dover Publications, NY.

Zanuttigh, B., van der Meer, J. W. 2008. Wave reflection from coastal structures in design conditions, Journal of Coastal Engineering, vol. 55, pp 771-779.

Zanuttigh, B., van der Meer, J. W., Andersen, T.L., Lara, J.L., Losada, I.J. 2008. Analysis of wave reflection from structures with berms through an extensive database and 2DV numerical modeling, Proceedings International Conference on Coastal Engineering, Hamburg, Germany, pp 3285-3297.

Zanuttigh, B., and van der Meer, J.W. 2007. Wave reflection from composite slopes, Proceedings of International Conference on Coastal Structures, ASCE Venice, Italy, pp 749-759. 